\title{
Measurement of thymus weight, lumbar node weight and progesterone levels in syngeneically pregnant, allogeneically pregnant, and pseudopregnant mice
}

\author{
Susan P. Chambers and Ann G. Clarke \\ Department of Obstetrics \& Gynaecology, City Hospital, Hucknall Road, Nottingham, \\ NG5 IPB, U.K.
}

\begin{abstract}
Summary. Female CBA mice were mated to fertile CBA males, to vasectomized CBA males, to fertile C57BL males or to vasectomized C57BL males. After allogeneic or syngeneic mating the extent of thymic involution on the 10th day of pregnancy and pseudopregnancy was similar. Lumbar lymph node weight was not affected by pseudopregnancy but increased similarly in allogeneic and syngeneic pregnancies.
\end{abstract}

Serum progesterone levels on the 10th day of pseudopregnancy were similar to those of non-pregnant females, and significantly lower than those of pregnant females. On the 4 th to 7 th days progesterone levels in pseudopregnant animals were equal to those in pregnant animals. Progesterone levels and thymic involution were similar in syngeneically and allogeneically pregnant females. Progesterone levels were negatively correlated with thymus weight but reached significance only when the mating was allogeneic. It is suggested that there is an interaction between progesterone concentrations and the degree of thymic involution during pregnancy.

\section{Introduction}

Maternal immunological unresponsiveness during pregnancy has been postulated as one of the mechanisms by which the embryo (Woodruff, 1957; Breyere \& Barratt, 1961) and other foreign tissues transplanted to the uterus (Beer \& Billingham, 1970) might escape rejection. Immunological factors (Hellström, Hellström \& Brawn, 1969) and hormonal changes of pregnancy have both been implicated to explain the general and specific depression in cell-mediated immunity. Corticosteroids (Kasakura, 1973), progesterone (Munroe, 1971), oestrogens (Waltman, Burde \& Berrios, 1971) and chorionic gonadotrophin (Contractor \& Davies, 1973; Adcock et al., 1973) have all been considered relevant.

In almost every animal studied (including man) involution of the thymus occurs during pregnancy. This involution lasts until after lactation when the thymus regenerates (Jolly \& Lieure, 1930; Persike, 1940a; Gregoire, 1947). In the mouse, it occurs to the same extent in syngeneic and allogeneic matings (Maroni \& De Sousa, 1973). Involution has been attributed to cell death within the thymus (Dougherty \& White, 1945; Metcalf, 1966), or to an exodus of small lymphocytes from the thymic cortex (Fichtellius, 1960; Ernström, 1970). The agents inducing thymic involution have been generally supposed to be corticosteroids (Diczfalusy \& Troen, 1961; Ishidate \& Metcalf, 1963; Burke \& Roulet, 1970), particularly cortisol (Maroni \& De Sousa, 1973). Exogenous cortisol causes involution of the thymus (Ishidate \& Metcalf, 1963) and levels of cortisol are known to rise in pregnancy (Burke \& Roulet, 1970).

There have been inconsistent reports about the changes occurring in the lumbar lymph nodes draining a pregnant uterus. Nelson \& Hall (1965) found no change in these nodes during 
pregnancy in women and attributed this lack of activity to elevated levels of corticosteroids. Several studies of the mouse, however, suggest that lumbar node weight increases during pregnancy, particularly in allogeneic pregnancy (Maroni \& De Sousa, 1973; Beer, Billingham \& Scott, 1975; Ansell, McDougal, Speedy \& Inchley, 1978), although this difference is not found in all strain combinations (Hetherington \& Humber, 1977). The increase in weight has been attributed to an immunological response to embryonic antigens. However, several studies have shown that corticosteroids and sex steroids can cause lymph node changes (Korenchevsky \& Hall, 1938; Persike, 1940b; Pepper, 1961; Pelner \& Rhoades, 1965).

During pregnancy hormonal changes and immunological stimulation by the embryo necessarily alter together and therefore the influence of each alone cannot be assessed in normal pregnancy. The present experiments attempted to separate these features in vivo by using pseudopregnant animals. We have examined on the 10th day of pregnancy two measurable immunological features which alter during pregnancy; thymic involution and changes in the weights of the draining nodes of the uterus, i.e. the lumbar nodes. At the same time we have measured one of the pregnancy hormones, progesterone, to discover if natural levels of this hormone are related to the immunological changes. We have also determined the concentration of serum progesterone earlier in pregnancy (2nd to 7 th day) in pregnant and pseudopregnant mice.

\section{Materials and Methods}

The mice used were of the C57BL/10ScSn $\left(\mathrm{H}-2^{\mathrm{b}}\right)$ and $\mathrm{CBA} / \mathrm{Ca}\left(\mathrm{H}-2^{\mathrm{k}}\right)$ strains from OLAC Ltd, they are subsequently referred to as C57BL and CBA respectively. Mature mice (approximately 25 weeks old) were used because thymus weight declines rapidly in early adult life but later become relatively stable (Nandi, 1959).

\section{Experiment 1}

Allogeneic matings were obtained by allocating CBA female mice at random to three groups: those in Group 1 were mated to fertile C57BL mates, those in Group 2 to vasectomized C57BL males, and those in Group 3 were left unmated. For the syngeneic matings, three similar groups (Groups 4-6) of CBA females were set up, but CBA males were used. The mice were weighed and killed on the 10th day (1st day of pregnancy and pseudopregnancy = day of finding copulation plug).

\section{Experiment 2}

In this study of progesterone concentrations soon after mating, age-matched CBA females were mated to either fertile or vasectomized C57BL males or were left unmated. Mice were killed on the 2nd, 4th or 7 th day after finding the copulation plug. Pregnancy on the 2 nd day was confirmed by the presence of fertilized eggs in the oviduct. Pregnancy on the 4th day was confirmed by the pontamine blue reaction (McLaren, 1969). Pontamine blue $(0.2 \mathrm{ml}$ of a $0.5 \%$ solution: Gurr's $5 \mathrm{Bx}$ ) was injected intravenously $15 \mathrm{~min}$ before killing. Animals without eggs and blue implantation areas were excluded from the experiment.

Serum samples were collected by cardiac puncture at autopsy and were assayed for progesterone by a standard radioimmunoassay method similar to those described by Abraham, Swerdloff, Tulchinsky \& Odell (1971) and Kutas, Chung, Bartoss \& Castro (1972). The progesterone was extracted with hexane from serum and the dried residue dissolved in buffer. The isotope and antibody were equilibrated by incubation at $37^{\circ} \mathrm{C}$ and incubated at $4^{\circ} \mathrm{C}$. Duplicate assays were carried out on a single hexane extraction of serum. The bound and free 
fractions were separated by the use of Dextran-coated charcoal at $4^{\circ} \mathrm{C}$. The bound fraction was counted in a liquid scintillation counter and the progesterone concentration computed from a standard curve. The antiserum used was raised in rabbits against progesterone-11-hemisuccinate (Eurotope Services). The major cross-reacting steroids of this preparation are $4 \%$ for $17 \alpha$-hydroxyprogesterone; $2 \%$ for cortexone; $1.5 \%$ for pregnenolone; $<0.5 \%$ for all others. The tracer used was $\left[{ }^{3} \mathrm{H}\right]$ progesterone (sp. act. $300 \mu \mathrm{Ci} / \mu \mathrm{g}$ ). All results were expressed in nanomoles (nmol) per litre (l). The inter- and intra-assay variations were determined by using low and high quality controls (Ortho III and IV diagnostic controls) and gave intra-assay coefficients of variation of $11.2 \%$ (s.d. $0.72 \mathrm{nmol} / \mathrm{l}$ ) and $7.8 \%$ (s.d. $2.0 \mathrm{nmol} / 1$ ) respectively. The inter-assay coefficient of variation for the high-quality control was $9.4 \%$ (s.d. $2.4 \mathrm{nmol} / \mathrm{l}$ ). The method was sufficiently sensitive to detect $0.2 \mathrm{nmol}$ progesterone $/$.

Thymus and lumbar nodes were dissected out, cleared of fat, blotted once and weighed to the nearest milligram.

Differences in thymus weight, lumbar node weight and progesterone concentration were analysed for overall heterogeneity using the one-way analysis of variance, and group means were compared using the Students $t$ test. Regression analysis of thymus weight on progesterone levels was assessed by the method of Bailey (1959).

\section{Results}

\section{Experiment 1}

Allogeneic matings. The results are given in Table 1 . Mean thymus weights in the pseudopregnant and pregnant animals were very similar, and were both significantly lower than those in the non-pregnant mice (overall heterogeneity, $\mathrm{F}=24.0$, d.f. $=2,47, P<0.001$; comparison between pseudopregnant and non-pregnant, $t=5.75$, d.f. $=30, P<0.001$; comparison between pregnant and non-pregnant, $t=5.91$, d.f. $=32, P<0.001$ ). Lumbar node weights in the pregnant mice were higher than those in the pseudopregnant and non-pregnant groups, but the difference did not reach overall significance.

Mean progesterone levels were approximately 5 times higher in pregnant animals than they were in pseudopregnant and non-pregnant animals $(\mathrm{F}=85.0$, d.f. $=2,43, P<0.001)$. There was no difference in progesterone levels between pseudopregnant and non-pregnant animals, indicating that concentrations in pseudopregnant mice had returned to non-pregnant levels by the 10th day. Progesterone levels were significantly negatively correlated with thymus weight in allogeneically pregnant animals (see Text-fig. 1a). There was no significant correlation for the pseudopregnant or non-pregnant animals. A comparison of the estimated slopes showed that that of the pregnant animals was significantly different from that of the non-pregnant mice.

Table 1. Mean \pm s.e.m. values for thymus weight, lumbar node weight and progesterone concentrations in allogeneically (Groups 1-3) and syngeneically (Groups 4-6) pregnant, pseudopregnant and non-pregnant mice

\begin{tabular}{clcccc}
\hline Group & $\begin{array}{c}\text { Reproductive } \\
\text { state }\end{array}$ & $\begin{array}{c}\text { No. of } \\
\text { animals }\end{array}$ & $\begin{array}{c}\text { Thymus wt } \\
(\mathrm{mg})\end{array}$ & $\begin{array}{c}\text { Lumbar node } \\
\text { wt (mg) }\end{array}$ & $\begin{array}{c}\text { Progesterone } \\
\text { conc. (nmol/l) }\end{array}$ \\
\hline 1 & Pregnant & 18 & $17.61 \pm 0.85$ & $4.44 \pm 0.24$ & $150.88 \pm 9.97$ \\
2 & Pseudopregnant & 16 & $17.93 \pm 0.77$ & $3.61 \pm 0.30$ & $25.99 \pm 4.59$ \\
3 & Non-pregnant & 16 & $26.37 \pm 1.25$ & $3.73 \pm 0.40$ & $30.76 \pm 7.40$ \\
4 & Pregnant & 15 & $22.40 \pm 0.86$ & $5.92 \pm 0.49$ & $107.53 \pm 10.33$ \\
5 & Pseudopregnant & 17 & $22.38 \pm 1.59$ & $4.21 \pm 0.23$ & $19.06 \pm 6.02$ \\
6 & Non-pregnant & 16 & $32.19 \pm 1.21$ & $4.75 \pm 0.23$ & $24.33 \pm 7.18$ \\
\hline
\end{tabular}




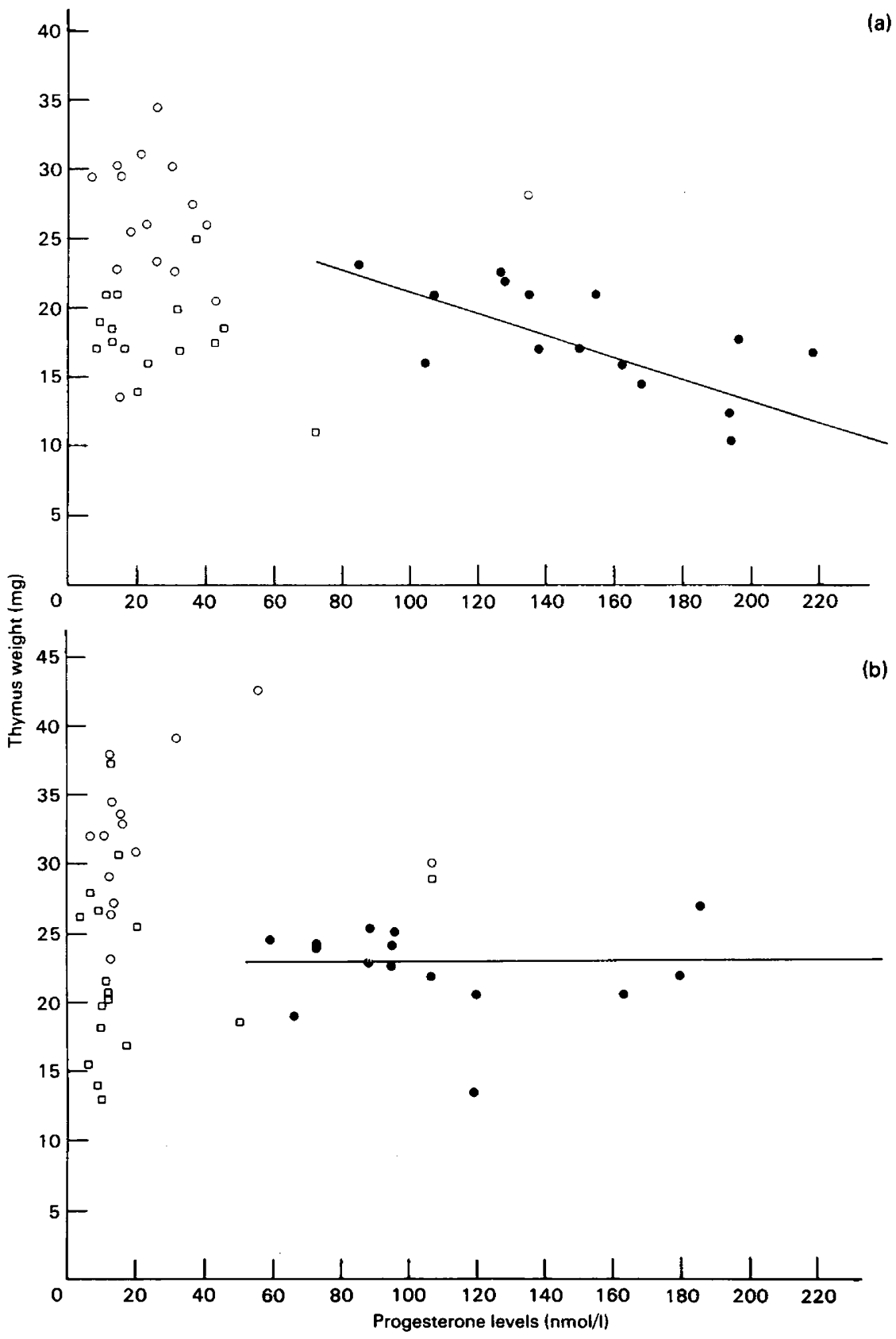

(a)

(b)

Text-fig. 1. The association between progesterone and thymus weight in (a) allogeneically and (b) syngeneically pregnant $(O)$, pseudopregnant $(\square)$ and non-pregnant $(O)$ mice. The regression equations for the pregnant mice are (a) $b=0.06 \pm 0.02(P<0.01)$ and (b) $b=$ $0.003 \pm 0.02$ (N.S.).

Syngeneic matings. In the syngeneically mated mice, as in allogeneically mated ones, the thymus weights of the pseudopregnant and pregnant animals were similar, and both were significantly smaller than those of non-pregnant mice $(\mathrm{F}=19.3$, d.f. $=2,47, P<0.001 ; t=$ 4.86, d.f. $=31, P<0.001 ; t=6.52$, d.f. $=29, P<0.001$, respectively; see Table 1). 
As in the allogeneic matings, lumbar node weights of pregnant animals were higher than those in the pseudopregnant and non-pregnant mice, but the differences were clearly significant (F $=6.96$, d.f. $=2,45, P<0.01 ; t=3.28$, d.f. $=30, P<0.01$, and $t=2.20$, d.f. $=29, P<$ 0.05 , respectively).

Levels of progesterone were approximately $4 \frac{1}{2}$ times higher in pregnant than in nonpregnant and pseudopregnant animals $(F=39$, d.f. $=2,47, P<0.001)$. There was no significant correlation between progesterone levels and thymus weight in any of the syngeneic matings (see Text-fig. 1b).

\section{Experiment 2: serum progesterone concentrations after mating}

Table 2 shows that serum progesterone concentrations rose similarly in pregnant and pseudopregnant animals and there were no significant differences between the concentrations on the 2nd, 4th or 7th day. In pregnant animals mean progesterone levels were significantly higher on the 2nd day compared with values in non-pregnant animals $(t=6.6$, d.f. $=15, P<0.001)$; on the 4th day compared with the 2 nd day $(t=9.43$, d.f. $=11, P<0.001)$; and on the 7 th day compared with the 4 th day $(t=2.66$, d.f. $=12, P<0.05)$. In pseudopregnant mice, concentrations were significantly higher on the 2 nd day than in unmated animals $(t=4 \cdot 30$, d.f. $=15, P<$ $0.001)$; on the 4 th day than on the 2 nd day $(t=17.96$, d.f. $=8, P<0.001)$; and on the 7 th day than on the 4th day (not significant).

Table 2. Mean \pm s.e.m. values for progesterone concentrations in pregnant and pseudopregnant mice on the 2 nd, 4 th and 7 th days after mating

\begin{tabular}{llcc}
\hline $\begin{array}{c}\text { Day after } \\
\text { mating }\end{array}$ & $\begin{array}{c}\text { Reproductive } \\
\text { state }\end{array}$ & $\begin{array}{c}\text { No. of } \\
\text { animals }\end{array}$ & $\begin{array}{c}\text { Progesterone } \\
\text { conc. (nmol/l) }\end{array}$ \\
\hline \multirow{2}{*}{ 2nd } & Non-pregnant & 12 & $20 \cdot 28 \pm 1.65$ \\
\hline 4th & Pregnant & 6 & $39.97 \pm 2.29$ \\
& Pseudopregnant & 5 & $38 \cdot 36 \pm 5 \cdot 38$ \\
\hline 7 th & Pregnant & 7 & $126 \cdot 54 \pm 8 \cdot 22$ \\
& Pseudopregnant & 5 & $115.68 \pm 9.30$ \\
\hline & Pregnant & 7 & $145.77 \pm 5.63$ \\
& Pseudopregnant & 6 & $133.07 \pm 9.01$ \\
\hline
\end{tabular}

\section{Discussion}

In the syngeneic and allogeneic matings, thymic involution on the 10th day after mating occurred to the same extent regardless of whether the animals were pregnant or pseudopregnant. This suggests that the factors responsible for thymic involution during pregnancy are the same as those responsible for thymic involution in pseudopregnancy. Thymic involution is therefore probably due to the presence of pregnancy-associated hormonal changes, and is independent of the presence of an embryo.

Increases in lumbar node weight occurred only in the pregnant animals and would, therefore, appear to be dependent upon the presence of an embryo. An increase in the weights of lumbar lymph nodes occurred in the allogeneic and syngeneic matings but was only significantly increased in the latter. In this particular mouse strain combination (CBA $q \times \mathrm{C57BL}^{-}$) lumbar node weight increase is not greater, in fact is rather less, in an outbred mating than in an inbred 
mating. This result is in agreement with the findings of Hetherington \& Humber (1977) that lumbar node weight increase is not necessarily associated with allogeneic mating.

Our results show that during both allogeneic and syngeneic pregnancies progesterone levels on the 10th day are appreciably higher in pregnancy than in pseudopregnancy or in control animals. Although the progesterone levels of pseudopregnant and non-pregnant animals are similar on the 10th day, they are not at earlier stages of preganancy. On the 4th to 7 th days concentrations in pseudopregnant animals equal the values found in pregnant animals. Thus, it is possible that progesterone may play a role in the thymic involution of pseudopregnancy.

Progesterone is known to be an immunosuppressive agent (Munroe, 1971). Some progesterone derivatives increase allograft survival time (Hulka, Mohr \& Lieberman, 1965; Pelner \& Rhoades, 1965; Turcotte, Haines, Brody, Meyer \& Schwarz, 1968) and have been shown to depress delayed type sensitivity (Carter, 1976). More recently progesterone has been shown to suppress P.P.D.- and P.H.A.-induced lymphocyte transformation (Wyle \& Kent, 1977). The thymus has two metabolizing enzymes for progesterone (Weinstein \& Lindner, 1977). We have found that injection of progesterone in amounts found in early pregnancy causes a significant involution of the thymus (unpublished observations).

Our results show that, in allogeneic pregnancy, the progesterone levels on the 10th day of pregnancy are correlated with the degree of thymic involution. The relationship is less clear in syngeneic matings. Taking into account the role of the thymus in the suppression of the immune response (Ha \& Waksman, 1973; Nachtigal, Zan-Bar \& Feldman, 1975; Reinisch, Andrew \& Schlossman, 1977) and the immunosuppressive effects of progesterone (see above), this correlation suggests an interaction between progesterone and immunological factors during pregnancy. This interaction may play a part in maternal tolerance to paternally inherited and embryo-specific antigens.

Our sincere thanks are due to Mr C. Selby, F.I.M.L.S., and Mrs S. Holmes for assaying the serum progesterone levels. We thank $\operatorname{Dr} \mathrm{A}$. McLaren for useful discussion, Professor B. C. Clarke for statistical advice and for critically reading the manuscript, and Professor E. M. Symonds for help and facilities. The work was supported by a grant from the Medical Research Council.

\section{References}

Abraham, G.E., Swerdloff, R., Tulchinsky, D. \& Odell, W.D. (1971) Radioimmunoassay of Plasma Progesterone. J. clin. Endocr. Metab. 32, 619-624.

Adcock, E.W., HI, Teasdale, T., Agust, C.S., Cox, S., Meschia, G., Battaglia, F.C. \& Naughton, M.A. (1973) Human chorionic gonadotrophin: its possible role in maternal lymphocyte suppression. Science, N.Y. 181, 845-847.

Ansell, J.D., McDougall, C.M., Speedy, G. \& Inchley, C.J. (1978) Changes in lymphocyte accumulation and proliferation in the lymph nodes draining the pregnant uterus. Clin. Exp. Immunol. 31, 397-407.

Balley, N.T.J. (1959) Regression analysis. In Statistical Methods in Biology, pp. 91-100. The English Universities Press Ltd, London.

Beer, A.E. \& Billingham, R.E. (1970) Implantation, transplantation and epithelial-mesenchymal relationships in the rat uterus. J. exp. Med. 132, 721-736.

Beer, A.E., Billingham, R.E. \& Scott, J.R. (1975) Immunogenetic aspects of implantation, placentation and feto-placental growth rates. Biol. Reprod. 12, 176-189.
Breyere, E.J. \& Barratt, M.K. (1961) Tolerance induced by parity in mice incompatible at the H-2 Locus. $J$. natn. Cancer Inst. 24, 409-413.

Burke, C.W. \& Roulet, F. (1970) Increased exposure of tissues to cortisol in late pregnancy. $B r$. med. J. 1, $657-659$.

Carter, J. (1976) The effect of progesterone, oestradiol and HCG on cell-mediated immunity in pregnant mice. J. Reprod. Fert. 46, 211-216.

Contractor, S.F. \& Davies, H. (1973) Effect of human chorionic gonadotrophin on phytohaemagglutinininduced lymphocyte transformation. Nature, New Biol. 243, 284-286.

Diczfalusy, E. \& Troen, P. (1961) Endocrine functions of the human placenta. Vitams Horm. 19, 229-311.

Dougherty, T.P. \& White, A. (1945) Functional alterations in lymphoid tissue induced by adrenal cortical secretion. Am. J. Anat. 77, 81-116.

Ernström, U. (1970) Hormonal influences on thymic release of lymphocytes into the blood. In Hormones and the Immune Response (CIBA Fndn Study Group No. 36), pp. 53-60. Eds G. E. Wolstenholme \& J. Knight. Churchill, London. 
Fichtellius, K.E. (1960) The destination of thymus lymphocytes. In Haemopoiesis; Cell Production and its Regulation (CIBA Fndn Symp.), pp. 204-220. Eds G. E. Wolstenholme \& M. O'Connor. Churchill, London.

Gregoire, C.H. (1947) Factors involved in maintaining involution of the thymus during suckling. $J$. Endocr. $5,68-87$.

Ha, T.Y. \& Waksman, B.H. (1973) Role of the thymus in tolerance. X. "Suppressor" activity of antigenstimulated rat thymocytes transferred to normal recipients. J. Immun. 110, 1290-1299.

Hellström, K.E., Hellström, I. \& Brawn, J. (1969) Abrogation of cellular immunity to antigenically foreign mouse embryonic cells by a serum factor. Nature, Lond. 224, 914-915.

Hetherington, C.M. \& Humber, D.P. (1977) The effect of pregnancy on lymph node weight in the mouse $J$. Immunogenet. 4, 271-276.

Hulka, J.F., Mohr, K. \& Lieberman, W. (1965) Effect of synthetic progestational agents on allograft rejection and circulating antibody production. Endocrinology 77, 897-901.

Ishidate, M. \& Metcalf, D. (1963) The pattern of lymphopoiesis in the mouse thymus after cortisone administration or adrenalectomy. Aust. J. exp. Biol. Med. Sci. 41, 637-649.

Jolly, J. \& Lieure, C. (1930) Influence de la gestation sur le thymus. C. r. Séanc. Soc. Biol. 104, 451-454.

Kasakura, S. (1973) Is cortisol responsible for inhibition of M.L.C. reactions by pregnancy plasma? Nature, Lond. 246, 496-497.

Korenchevsky, V. \& Hall, K. (1938) Effect of progesterone on metaplasia of uterine epithelium of rats injected with oestrogens. J. Obstet. Gynaec. Br. Commonw. 45, 22-29.

Kutas, M., Chung, A., Bartoss, D. \& Castro, A. (1972) A simple progesterone radioimmunoassay without column chromatography. Steroids 20, 697-716.

Maroni, E.S. \& De Sousa, M.A.B. (1973) The lymphoid organs during pregnancy in the mouse, a comparison between a syngeneic and an allogeneic mating. Clin. exp. Immunol. 31, 107-124.

McLaren, A. (1969) Transfer of zona-free mouse eggs to uterine foster mothers. J. Reprod. Fert. 19, 341-346.

Metcalf, D. (1966) The thymus-its role in immune responses, leukaemia development and carcinogenesis. In Recent Results in Cancer Research, Vol. 5, pp. 27-32. Ed. P. Retchnick. Springer-Verlag, Berlin.
Munroe, J.S. (1971) Progesteroids as immunosuppressive agents. J. Reticuloendoth. Soc. 9, 361375 .

Nachtigal, D., Zan-Bar, I. \& Feldman, M. (1975) The role of specific suppressor T-cells in immune tolerance. Transplant. Rev. 26, 87-105.

Nandi, S. (1959) Hormonal control of mammogenesis and lactogenesis in the $\mathrm{C} 3 \mathrm{H} / \mathrm{He} \mathrm{Crgl}$ mouse. Univ. Calif. Publs Zool. 65, 1-71.

Nelson, J.H. \& Hall, J.E. (1965) Studies on the thymolymphatic system in humans. I. Morphological changes in lymph nodes in pregnancy at term. Am. J. Obstet. Gynec. 90, 482-484.

Pelner, L. \& Rhoades, M.G. (1965) Host-tumour antagonism. XXXIV. The use of progestational agents to retard homograft rejection in rabbits; a pilot study. J. Am. Geriat. Soc. 13, 765-771.

Pepper, F.J. (1961) The effect of age, pregnancy and lactation on the thymus gland and lymph nodes of the mouse. J. Endocr. 22, 335-348.

Persike, E.C. (1940a) Involution of the thymus during pregnancy in young mice. Proc. Soc. exp. Biol. Med. 45, 315-317.

Persike, E.C. (1940b) Involution of the thymus of the young albino rat under treatment with testosterone propionate. Am.J. Physiol. 130, 384-391.

Reinisch, C., Andrew, S.L. \& Schlossman, S.F. (1977) Suppressor cell regulation of immune response to tumours; abrogation by adult thymectomy. Proc. natn. Acad. Sci. U.S.A. 74, 2989-2992.

Turcotte, J.G., Haines, R.F., Brody, G.L., Meyer, T.J. \& Schwartz, S.A. (1968) Immuno-suppression with medroxyprogesterone acetate. Transplantation 6, 248-260.

Waltman, S.R., Burde, R.M. \& Berrios, J. (1971) Prevention of corneal homograft rejection by estrogens. Transplantation 11, 194-196.

Weinstein, Y. \& Lindner, H.R. (1977) Thymus metabolises progesterone-possible enzymic marker for $T$ lymphocytes. Nature, Lond. 266, 632-633.

Woodruff, M.F.A. (1957) Transplantation, immunity and immunological problems of pregnancy. Proc. $R$. Soc. $B$ 148, 68-75.

Wyle, F.A. \& Kent, J.R. (1977) Immunosuppression by sex steroid hormones. 1. The effect upon PHA \& PPD-stimulated lymphocytes. Clin. exp. Immunol. $27,407-415$.

Received 12 April 1978 